All previous reports on acute focal bacterial nephritis have been published in urological or radiological journals ${ }^{1-6}$ and it has yet to receive individual coding in the international classification of diseases. It is probable, therefore, that this disorder is often not recognised due to lack of awareness of the diagnosis. In addition, early treatment with antibiotics can no doubt lead to resolution before progression to abscess formation, and only the use of ultrasound or computed tomography in the acute stage can accurately identify this disease entity. Nevertheless, when encountered, precise diagnosis is important so that acute focal bacterial nephritis can be appropriately and conservatively managed with parenteral antibiotics, avoiding unnecessary laparotomy or attempted percutaneous drainage.

We thank Miss D Ward and Mrs M Renwick for secretarial help, and $\mathrm{Mr} \mathrm{J}$ E S Scott for his constructive criticisms in the preparation of this report.

\section{References}

' Rosenfield AT, Glickman MG, Taylor KJW, Crade M, Hodson J. Acute focal bacterial nephritis (acute lobar nephronia). Radiology 1979;132:553-61.

2 Lebowitz RL, Fellows KE, Colodny AH. Renal parenchymal infections in children. Radiol Clin North Am 1977;15:37-47.

${ }^{3}$ Kuligowska E, Newman B, White SJ, Caldarone A. Interventional ultrasound in detection and treatment of renal inflammatory disease. Radiology 1983;147:521-6.

${ }^{4}$ Siegel MJ, Glasier CM. Acute focal bacterial nephritis in children: significance of ureteral reflux. Am J Radiol 1981;137:257-60.

5 Hoddock W, Jeffrey RB, Goldberg HI, Federle MP, Laing FC. $\mathrm{CT}$ and sonography of severe renal and perirenal infections. Am J Radiol 1983;140:517-20.

${ }^{6}$ Funston MR, Fisher KS, van Blerk PJP, Bortz JH. Acute focal bacterial nephritis and renal abscess? A sonographic diagnosis. Br J Urol 1982;54:461-6.

Correspondence to Dr G R Lawson, Department of Child Health, The Medical School, Framlington Place, Newcastle upon Tyne, NE2 $4 \mathrm{HH}$.

Received 10 January 1985

\title{
Remission of progressive renal failure in familial Mediterranean fever during colchicine treatment
}

\author{
T HERLIN, K STORM, AND B HAMBORG-PETERSEN
}

Department of Paediatrics, Aarhus Kommunehospital, University of Aarhus, Denmark

SUMMARY Colchicine was administered to a 12 year old girl with familial Mediterranean fever and progressive renal insufficiency. There was immediate resolution of abdominal attacks together with a dramatic fall in the serum creatinine concentration and the degree of proteinuria. At the same time her severely impaired growth was stimulated.

Familial Mediterranean fever is an inherited disease with recurrent inflammation of the joints and the pleural and peritoneal cavities. Development of amyloidosis in this disease is fairly common and is seen in one third of patients during the first two decades of life. ${ }^{1}$ Onset of familial Mediterranean fever amyloidosis in childhood indicates a poor prognosis, with only $20 \%$ survival 5 years after proteinuria has developed, ${ }^{2}$ and no spontaneous regression of renal failure has been reported. ${ }^{1}$ Colchicine has been shown to reduce the severity and frequency of attacks. ${ }^{3}$ We describe the course of progressive renal failure in a 12 year old girl with familial Mediterranean fever which remitted during colchicine treatment.

\section{Case report}

This girl was the first of three children of Turkish parents. From 5 years of age she had suffered recurrent attacks of abdominal pain. She was admitted to our department when 11 years old, shortly after arriving in Denmark as an immigrant. She was chronically disabled with oedema of hands and feet, anaemia (haemoglobin $9.6 \mathrm{~g} / \mathrm{dl}$ ), hepatomegaly, height $107 \mathrm{~cm}$ (less than -3 SD), weight $18 \mathrm{~kg}$ (less than $-3 \mathrm{SD}$ ), and erythrocyte sedimentation rate $97 \mathrm{~mm}$ in the first hour. Proteinuria was present (10 g/day), but her renal function was normal (creatinine clearance $94 \mathrm{ml} /$ minute, serum creatinine value $33 \mu \mathrm{mol} / \mathrm{l}$ ). The fibrinogen value was considerably raised at $10 \cdot 3 \mathrm{~g} / \mathrm{l}$. Blood pressure and liver function were normal. At first, nephrotic syndrome was suspected but a trial with prednisone produced no effect. Rectal biopsy showed amyloid infiltration and the clinical picture was consistent with familial Mediterranean fever (recurrent polyserositis). This disorder has subsequently been diagnosed in a cousin. Her abdominal symptoms partly subsided and she was treated with diuretics only. During autumn 1983 the abdominal attacks 


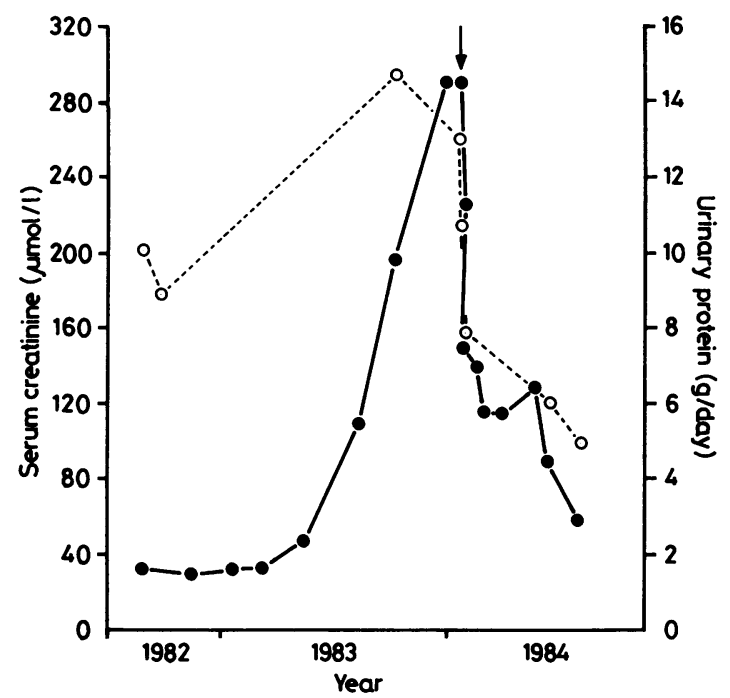

Figure Serum creatinine and urinary protein concentrations during observation period in patient with familial Mediterranean fever. Arrow indicates start of treatment with colchicine.

$\mathrm{O}---\mathrm{O}=$ urinary protein;

--- serum creatinine.

intensified and progressive renal failure was observed. The serum creatinine concentration rose to $290 \mu \mathrm{mol} / \mathrm{l}$ (Figure), creatinine clearance fell to $7 \mathrm{ml} /$ minute, and the erythrocyte sedimentation rate increased. Secondary hypoparathyroidism and hypotonicity of both legs were observed.

Treatment with colchicine was instituted with 0.5 mg twice daily for one week and thereafter $0.5 \mathrm{mg}$ daily. After this treatment began the spontaneous attacks abated immediately. A gradual fall in the serum creatinine concentration was observed during the next seven months (now $58 \mu \mathrm{mol} / \mathrm{l}$ ) (Figure) and creatinine clearance increased to $68 \mathrm{ml} /$ minute. Although proteinuria declined rapidly it is still considerable ( $4.8 \mathrm{~g} /$ day) (Figure). In addition an increase in haemoglobin, a fall in the erythrocyte sedimentation rate $(44 \mathrm{~mm}$ in the first hour) and parathyroid hormone values, and a reduction in liver size were observed as well as resolution of the neurological symptoms. Growth, which had been arrested for at least one year, was again stimulated and within the past 7 months her height has increased by $4 \mathrm{~cm}$. During treatment with colchicine no adverse side effects were observed, not even changes in bowel habits.

\section{Discussion}

The well known effect of colchicine of reducing the frequency and severity of abdominal attacks ${ }^{3}$ was observed dramatically in this patient. A steady fall in the serum creatinine value, proteinuria, and the erythrocyte sedimentation rate were seen immediately after treatment began, together with the relief of uraemic symptoms. Normal renal function returned after seven months, but proteinuria has persisted.

Colchicine seems to prevent amyloid deposits in experimental mice by blocking the release of amyloid A precursors from the neutrophils. ${ }^{4}$ Long term colchicine treatment in familial Mediterranean fever amyloidosis is followed by a gradual decrease in the degree of proteinuria. ${ }^{5}$ Remission of renal failure in this disorder, however, has not been reported, even during colchicine treatment. The rapid fall in serum creatinine (halved within one week) and in the degree of proteinuria after beginning this drug, without any other medication, makes it probable that colchicine is responsible for the improvement of renal function in our patient. Although renal biopsy was not undertaken, renal amyloidosis is extremely probable ${ }^{2}$ since our patient had Mediterranean fever with nephrotic syndrome, renal failure, and a positive rectal biopsy. The clinical picture and the time related colchicine response argue against the possibility that the improvement in renal function was due to resolution of a renal venous thrombosis often associated with this disease. ${ }^{6}$

In a review describing the course of 35 children with amyloidosis and familial Mediterranean fever, growth retardation was not observed. ${ }^{2}$ Although growth arrest is known in uraemic patients, this girl presented with very short stature even before severe renal impairment was found. The onset of growth after beginning colchicine may indicate a relation between growth retardation and systemic amyloidosis. Relief of peripheral neuropathy symptoms and reduction of liver enlargement may further indicate the systemic effect of colchicine. Our results show that colchicine, in the treatment of familial Mediterranean fever, besides its preventive effect on acute spontaneous attacks, may also cause regression of amyloidosis which otherwise progresses relentlessly.

\footnotetext{
References

1 Sohar E, Gafni J, Pras M, Heller H. Familial Mediterranean fever. A survey of 470 cases and a review of the literature. $A m J$ Med 1967;43:227-53.

2 Ludomirsky A, Passwell J, Biochis H. Amyloidosis in children with familial Mediterranean fever. Arch Dis Child 1981;56: 464-7.

3 Dinarello CA, Wolff SM, Goldfinger SE, Dale DC, Alling DW. Colchicine therapy for familial Mediterranean fever: a double blind trial: $N$ Engl J Med 1974;291:934-7.
} 
${ }^{4}$ Kedar I, Ravid M. The role of polymorphnuclear leukocytes and $\mathrm{T}$ lymphocytes in experimental murine amyloidosis. Eur $J$ Clin Invest 1980;10:63-8.

5 Ravid M, Robson M, Kedar I. Prolonged colchicine treatment in four patients with amyloidosis. Am Intern Med 1977;87: 568-70.
${ }^{6}$ Barclay GPT, Cameron HM, Loughridge LW. Amyloid disease and renal vein thrombosis. $Q J$ Med 1960;29:137-51.

Correspondence to Dr T Herlin, Department of Pediatrics, Aarhus Kommunehospital, DK-8000 Aarhus C, Denmark.

Received 10 December 1984

\title{
Prognosis for babies born with fused eyelids
}

\author{
G CROSS, M BECKER, AND P CONGDON \\ Regional Neonatal Intensive Care Unit and University of Leeds, Department of Paediatrics and \\ Child Health, Leeds General Infirmary
}

SUMMARY The overall mortality for babies referred to our unit with fused eyelids was $68.7 \%$; but when severe skin bruising was present only one of 18 babies survived $(5 \cdot 6 \%)$. This compares with a survival rate of $75 \%$ for those not bruised at or soon after birth. Skin bruising invariably indicates a very poor prognosis in babies born with fused eyelids.

The idea of a 'cut off' weight below which intensive care could be withheld for babies born at the extremes of viability has been suggested. ' Although mortality increases with decreasing birthweight, survival rates of $40 \%$ have been reported for babies born between 501 and $750 \mathrm{~g} .{ }^{2}$ Birthweight cannot, therefore, be used as the sole criterion when deciding whether to initiate or withdraw intensive care. Although each unit develops its own criteria in the light of previous experience, paediatricians often find the outcome for babies treated in other units helpful when counselling parents. For this reason we report our findings for a group of babies born with fused eyelids (gestation 24 to 27 weeks).

\section{Patients}

Between June 1981 and November 1983, 319 babies were admitted to our neonatal intensive care unit for respiratory support. The neonatal unit in our hospital at this time was atypical in that there was no maternity unit on site and all babies requiring ventilatory support were transferred. Retrospective analysis of case notes showed that $32(10 \%)$ of these babies had fused eyelids, and in all but two this was bilateral. Their birthweights ranged from 500 to $970 \mathrm{~g}$ (mean $755 \mathrm{~g}$ ) with estimated gestational ages of 24 to 27 weeks (calculated from the mother's menstrual dates). Only 10 of these $32(31 \%)$ babies survived to be discharged from the unit. Of the 19 with birthweights equal to or less than $800 \mathrm{~g}$, four survived $(21.5 \%)$ but six of the $14(43 \%)$ with birthweights greater than $800 \mathrm{~g}$ survived. Bruising, noticeable within the first hours of life (usually affecting both legs, the lower abdomen, or the head), was present in 18 of 30 (no record was made in two cases). Only $1(5 \cdot 6 \%)$ of these 18 survived compared with nine of $12(75 \%)$ without bruising. There were no survivors in 11 newborns with bruising, fused eyelids, and a birthweight under $800 \mathrm{~g}$. The Table summarises these findings. A full necropsy was available in only 14 of the 32 babies with fused eyelids. Twelve of these 14 were bruised at birth and seven had an associated intraventricular haemorrhage $(59 \%)$. Twelve babies died within 24 hours (mean birthweight $765 \mathrm{~g}$ ) and eight died within the next seven days (mean birthweight $690 \mathrm{~g}$ ). Of the two remaining babies, one died aged 39 days with gross hydrocephalus secondary to a large intraventricular haemorrhage and the other died at 3 months from severe bronchopulmonary dysplasia. Two of the 10 survivors subsequently died unexpectedly as cot deaths when aged 5 and 15 months. Follow up examinations have been completed for all the others, and while none has a profound handicap, as the oldest is still only 23

Table Outcome for babies born with fused eyelids $(F E)$ in relation to birthweight and presence of bruising

\begin{tabular}{rlll}
\hline No & Birthweight $(g)$ & $\begin{array}{l}\text { Physical } \\
\text { characteristics }\end{array}$ & Survival (\%) \\
\hline 19 & $\leqslant 800$ & $\mathrm{FE}$ only & $4(21 \cdot 5)$ \\
13 & $>800$ & $\mathrm{FE}$ only & $6(46 \cdot 15)$ \\
11 & $\leqslant 800$ & $\mathrm{FE}+$ bruised & $0(0)$ \\
6 & $\leqslant 80(0)$ & $\mathrm{FE}+$ not bruised & $4(66 \cdot 6)$ \\
7 & $>8(0)$ & $\mathrm{FE}+$ bruised & $1(14)$ \\
6 & $>800$ & $\mathrm{FE}+$ not bruised & $5(83 \cdot 3)$ \\
18 & & $\mathrm{FE}+$ bruised & $1(5 \cdot 6)$ \\
12 & & $\mathrm{FE}+$ not bruised & $9(75)$ \\
\hline
\end{tabular}

